Volume 2

Number 1 Volume 2, Number 1 (March 2009)

Article 2

2009

\title{
Knowledge of the World and the Act of Judging
}

Robin Jacob

Follow this and additional works at: http:// digitalcommons.osgoode.yorku.ca/ohrlp

\section{Citation Information}

Jacob, Robin. "Knowledge of the World and the Act of Judging." Osgoode Hall Review of Law and Policy 2.1 (2014): 22-28.

http://digitalcommons.osgoode.yorku.ca/ohrlp/vol2/iss1/2

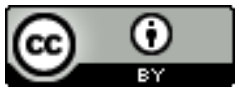

This work is licensed under a Creative Commons Attribution-NonCommercial-NoDerivs 3.0 Unported License.

This Lecture is brought to you for free and open access by the Journals at Osgoode Digital Commons. It has been accepted for inclusion in Osgoode Hall Review of Law and Policy by an authorized administrator of Osgoode Digital Commons. 


\section{LECTURE}

\section{KNOWLEDGE OF THE WORLD AND THE ACT OF JUdGING •}

The Right Honourable Lord Justice Jacob*

In this lecture the author notes that in order for judges to be seen to dispense justice they must possess a developed understanding of the world. This has important implications for how judges are to be chosen as well as whether, and if so how they are to be trained. Judges appointed from the bar will likely have a greater knowledge of the world, while a more inclusive, open and diverse selection procedure will enhance the prospect that justice will be perceived to be done. Judicial training, in turn, may increase judge's knowledge of the world, or at least the perception that justice is being done, Ultimately, knowledge of the world is a personal pursuit whose end lies in the ability to identify with the other - an instrumentally useful ability for a judge, and an inherently worthwhile activity for any person.

Lord Chief Justice Hewart once famously said: "Justice must not only be done but must manifestly and undoubtedly be seen to be done. " Did he require more than was necessary? Is it enough if justice is seen to be done: never mind if it is actually done? A purist might say not. But hear me out. In ancient China it is said there was a mythical one-horned beast called the xiezhi - the beast of justice. You put the plaintiff and defendant on either side of it. The one it touched with its horn lost. Not only was this much quicker and cheaper than all our current procedures, but it satisfied the population. Justice was seen to be done. From the point of view of society all was well. The same went for trial by ordeal, whether of fire, water, knives or some other horror - a process carried out not only in mediaeval Europe but in many other countries and cultures.

- (c) 2009 Sir Robin Jacob

* The Right Honourable Lord Justice Jacob, Justice of the Court of Appeal of England and Wales, in charge of the Intellectual Property List. The Justice's remarks were delivered at the Congrés de la Magistrature, Québec City, November 2008.

${ }^{1} R$ v. Sussex Justices, Ex parte McCarthy ([1924] 1 KB 256, [1923] All ER 233). 
Behind these methods of trial was the notion of a God directing justice. Judges derived their authority from God and did not need to explain themselves very much. Incidentally we still have vestiges of that - most particularly in the taking of the oath. Swearing to tell the truth by Almighty God is the default method for a witness - and it can still actually work. I once had a young Muslim man, made to lie by his overbearing and dishonest father, choke as he tried to take the oath on the Q'uoran.

Thing have moved on. Society now expects the act of judging to be carried out by a rational process of assessment and weighing of evidence: not only in relation to fact finding, but also in relation to the interpretation of the rules of law itself. For justice to be seen to be done, the modern judge must give reasons - to explain to a critical public why he or she decides a case. And most particularly, for justice to be seen to be done, the judge must explain why the losing party lost - which involves stating and answering that party's main points.

What can best place a judge to carry out this task? I start by saying what will not do - pomposity. A judge is a person of power and authority. There is a real danger it can go to his or her head. Common lawyers even have a word for this - "judgitis." I do not know whether other legal systems have a similar special word: whether they do or not I am sure they know the phenomenon.

In the early years of the industrial revolution and well into the $20^{\text {th }}$ century, in my country and I suspect most other common law countries, society placed the judge on a particularly high pedestal. Society itself encouraged judgitis. They even wanted it so that it could be ridiculed, as they still do. Here is a story from the Edwardian era about a particularly pompous, self-important man called Mr Justice Darling. A celebrity of the time was a music hall artist called George Robey - a household name. There came a case where F.E. Smith - later Lord Chancellor - was before Mr Justice Darling. He mentioned George Robey in the course of his address. "Who is George Robey?" asked Mr Justice Darling. F. E. Smith smiled: "Oh my Lord, he is the darling of the music halls."

Judgitis continued. In the year 1936 Chief Justice Hewart, in his speech to the Lord Mayor's Banquet: "Her majesty's judges are 
satisfied with the almost universal admiration in which they are held." And the press said nothing.

These days I believe that judgitis is a disease somewhat under control - though no one should ever think it can be eliminated and the fight against it must go on. It is think a personal fight for each judge.

The next thing to be avoided - an aspect of judgitis - is to appear unworldly. As if the things that are part of the life of the ordinary citizen are below his or her exalted status. Legend has it that a judge in the 1960s once asked "Who or what are the Beatles?" It was a legend - the story is attached to no particular judge, but it was credible. The press have told the story often since and will continue to do so.

So judgitis and remoteness are undesirable attributes. What about those which are desirable? Following the theme of "appearance" with which I started, a modern judge must at least appear to have knowledge of the world - I suppose we all ask teenage children or grandchildren about the names of popstars and celebs so as to at least appear "with it". In a music case involving Bruce Springsteen, when his counsel got up, I said: "Now I am supposed to ask, who is Bruce Springsteen?" in a what, with hindsight, seems a rather pathetic attempt to show I was at one with the common man.

But appearing to be at one with the common man - to be "with it" - is not enough either. The judge must appear more than superficially wordly - he (by which I include she) should in fact be so. Sometimes judicial reasoning explicitly appeals to knowledge of the world. Long ago, in 1877, Lord Justice James asked this question in a passing off case:

"Now, what could have been the only motive which can be suggested to a man of the world by a man of the world of the Defendants in doing that"'?

And in considering whether a magistrate was right to hold that what was really a permanent garage was not a "structure" because it was made of canvas on a fixed frame, Lord Goddard said:

${ }^{2}$ Orr-Ewing v Johnson (1877) 13 Ch. D 434 at 451. 
I think, therefore, that we must hold that the magistrate did not direct himself properly in this matter. Had he asked himself, as a man of the world, as an ordinary citizen - the man on the Stoke Newington bus - whether it was a structure. I think that he must have come to the conclusion that this was a structure ${ }^{3}$;

And of course the favourite child of the common law, the reasonable man - the man on the Clapham omnibus ${ }^{4}$ - le bon père de famille as you say in Québec - is a man of the world.

So, from the point of view of public acceptance of what we do, we must seem to be in touch - to have knowledge of the world. How is that to be achieved? The only really effective way to seem to be something is to be it. In reality it is not enough to seem to be in touch. You can't get away with pretending all the time. So a judge actually does require knowledge of the world.

This truth has important implications in at least two ways: how judges are to be chosen, and whether, and if so how, they are to be trained.

I start with judge appointment. The biggest difference across the world is between systems which have career judges and those which have judges appointed from practising lawyers. I once discussed this with a distinguished German lawyer who was about 50 years old at the time. I said: "would you like to be a judge?" After a long pause he said: "You know, I have never thought about it because it is not possible in Germany". Then, after another pause, he added: "But, yes." I thought 'what a pity'. The German judicial system was the loser. I have had similar discussions with French lawyers - with much the same response. The divide broadly follows the divide between common law and civil law countries. A few countries, (e.g. Holland), have a mixture between career-only and bar appointed judges. Some throw in the appointment of academics.

As regards knowledge of the world, I suspect few would challenge the proposition that a bar appointed judge is likely to be better placed than a career judge. A judge whose only worldly

${ }^{3}$ LCC v Tan [1954] 1 WLR 371.

${ }^{4}$ Attributed to Lord Bowen. 
experience is school, law at university, judge school, judicial continuing education and actual judging is not given much of a chance to learn the ways of the world. That is not to say that there are not many fine civil law judges, for there are. But it is surely easier to judge if one has experience of actual clients and of actual case preparation. The best gamekeepers were once poachers; as the saying goes "set a thief to catch a thief". There is confirmation from the opposite perspective: a good friend of mine, Jan Brinkhof, was the widely respected President of the Court of Appeal in the Hague. In his early 50s he changed course, becoming a practising lawyer for the first time. He says he was surprised to learn what real clients (and opponents) were like, that he wished he had had such experience when he was a judge. Another judge I know, Judge Lv Guo Quang, Vice President of the Shanghai No.2 Intermediate People's Court, spent three years during the Cultural Revolution out in the country planting vegetables and studying the Little Red Book. He did not like it much, but the knowledge of the world he gained has surely helped him as man and as a judge.

I turn to the process of judicial appointment. I can only really talk about what we do in England and Wales (remember Scotland is different). Other countries will have different systems but I suspect all of them have moved or will have moved along similar lines. In England it was once simple and cheap - but far from "transparent". A man from the Lord Chancellor's Office went round the judiciary and a few select others (e.g. the Chairman of the Bar) and took what were called "soundings." The Lord Chancellor then made an appointment. Formally it was by the Queen - in the case of the Court of Appeal and House of Lords judges on the recommendation of the Prime Minister. That is how it was done when I was appointed 15 years ago. Moreover there was no requirement of any prior training or judicial experience by way of sitting as a deputy judge. Other countries worried about this sort of thing earlier. Here is a story from the USA: Chief Justice Burger held a conference about judicial appointments where the need for prior assessment and training was discussed. A man from the Lord Chancellor's department was there as an observer. He was heard to murmur: "I don't see the problem. All we do is take a barrister and turn him round." 
Now things are different. There is political if not public pressure for greater openness and for diversity. A Judicial Appointments Commission was established in April 2006. It has a lay Chairman and 14 Commissioners, five judicial, five professional and five lay. The presence of the lay members shows something significant about a public perception that judges should have knowledge not merely of law but of the world. You would not sensibly put lay people on a panel choosing a brain surgeon or a professor of physics - though I daresay sometimes it is done. The Commission has explicit goals of equal opportunities and diversity of race and sex, though at the same time the ultimate criterion is merit. It goes about its work in an elaborate and necessarily bureaucratic way. People have to apply to be judges - even write an essay about why they think they would be good at it. Consultation forms are sent here there and everywhere - followed by elaborate short-listing and interviews. It costs nearly $£ 9 \mathrm{~m}$ a year to run - and that does not include any of the time put in by consultees.

Are English judges any more aware of the world, more diverse, as a result of all this? Not so far. It is early years but the number of women or black or Muslim appointees remains low. It will change in the future - simply because more able lawyers of these groups are coming through to appointable age. For myself I doubt whether the expensive change from secret soundings has produced any better, or indeed, different results. What has changed is perception- the appointees are seen to be chosen more fairly and to be more "of the world" than in times past.

Before finishing with judicial appointment I end with a question to which I do not know the answer. I have noticed that the proportion of women judges in Canada seems to be much higher than that in England or indeed anywhere else in the common world I have been. I do not know why and would like to. ${ }^{5}$ I would add that there is a very high proportion of women judges in France. One Judge told me why. She said: "we are paid very badly - like nurses - so we 'ave 'usbands who earn the money."

Next, and briefly, judicial training. Some countries have long had a substantial continuing programme of judicial training.

\footnotetext{
${ }^{5}$ When this talk was delivered, the Honourable Madam Justice Abella provided the answer - "in Canada, appointments are on merit."
} 
Germany, which spends more on its judiciary per head of population, has two permanent judicial training facilities for its Judges. In England we once had none. Now we have a Judicial Studies Board with an annual budget of about $£ 8 \mathrm{~m}$ - which of course does not include the cost of training provided by judges. This body clearly helps a lot with judicial awareness - and provides an important means of keeping judges in touch. Other countries are increasing judicial training - both of a formal kind and the informal kind provided by things such as this conference.

Of course none of this can really make us men or women with great knowledge of the world. It can help somewhat, but really it all depends on the individual. We can but do our best to remain aware, to listen, to read. And the wider our experience the more we can develop what I think is a key attribute - the ability to put yourself in the place of the other man or woman, whether they be litigant or witness or anyone else. This attribute is precious - beyond the courts one of the greatest protections against cruelty and one of the greatest forces for peace. The truth is that knowledge of the world, that is to say of others, is, or ought to be, an aspiration for everyone, whether they are judges or not . 